\title{
SYSTEMIC VECTORS OF INDIVIDUAL AND ORGANIZATIONAL DIMENSIONS IN EMERGENCE OF MOBBING IN EMPLOYEE RELATIONS
}

\section{Jolita Vveinhardt}

\author{
Lithuanian Sports University, Kaunas, Lithuania
}

\begin{abstract}
ANNOTATION
The purpose of this research article is pursued by analysing and systematising the results of the recent research, drawing the vectors of organizational environment, the change in direction which would influence the phenomenon preventively. In this article the causes of mobbing are analysed in two ways: in individual and organizational aspects, in order to answer the question of how to reduce the risk of mobbing by managerial actions, taking into account these criteria. The role of organizational system is highlighted as a factor, determining the emergence of bullying in the work environment. The analysis of individual causes of mobbing reveals that the attacks related to bullying are more likely to occur on personalities with exceptional features. The dynamics of organizational and individual factors, which affects bullying in organization and escalation of mobbing, was determined. The systematised findings of the most recent and earlier research suggest the topics for new studies of mobbing in relations within work organizations.
\end{abstract}

Keywords: mobbing, bullying, organizational system, individual, prevention.

\section{INTRODUCTION}

Conflicts within an organization are inevitable, however, constructive conflicts help the organization develop and effectively solve problems emerging in the market, and destructive conflicts disorganize work, stop professional development and undermine organizational activities. Mobbing is one of the most extreme forms of conflict, characterised by all the causes of conflicts, but the consequences are especially painful in both human and financial sense for an employee, as well as for the entire organization. Although workplace incivility has been found to negatively impact individual and organizational performance and interfere with the creation of a civil and respectful workplace, the phenomenon has been largely overlooked by the field of human resource development (Estes, Wang, 2008).

Opening economical and socio-cultural spaces, tendencies of globalization and demography, changes of work power raise the following objectives for the organizations: how to keep their professional employees; how to integrate the variety of persons (representatives of other nationalities and races, different cultures, religions, sexual orientation and different social group members), how to create and keep a proper level of organizational climate, which would guarantee the quality work results. It would be difficult to re-evaluate the meaning of employees' relationships and climate in the philosophy of the organizations that seek innovativeness in knowledge economics (Vveinhardt, Žukauskas, 2012).

Interest in the problem of mobbing in work organizations in Lithuania is increasing, however, for further research and prevention of the phenomenon in organizations there is a growing need to strengthen methodological basis and, on the grounds of the latest international research, to highlight the aspects that will help both researchers and executives of organizations of various 
professional fields to perceive the causes of the phenomenon. Hospitality industry is not the exception. K. van Heugten (2013) claims that the hospitality industry is one of the areas where the problem of mobbing is particularly relevant. The problem must be addressed by improving working conditions, reducing physical load, increasing awareness on the subject (Johns, Menzel, 1999). The research conducted in Lithuania has shown that the occurrence of mobbing in the activities of hotels and restaurants reaches almost 6 percent (Vveinhardt, 2010).

Bullying and the extreme form of terrorisation of employees, mobbing, are the factors, which adversely affect not only the organizational environment and outcomes, but also the individual's quality of life. The term "mobbing" is defined as antagonistic behaviors with unethical communication directed systematically at one individual by one or more individuals in the workplace (Yildirim et al., 2007). There is a connection between the attacks they experience in the work environment and social behaviour of the person outside the organization, i. e., in different areas of life, from relations in the family, relations with friends and acquaintances to the availability of cultural industries. This is related to an individual's social self-isolation, decrease of the purchasing power and psychosomatic disorders of body functions.

The acceptance of bullying in an organization means that the conflict of mobbing already exists in the organization or bullying can turn into mobbing. Mobbing differs from what is named by the term bullying in scientific literature in the English language, the term sometimes used as a synonym for mobbing, by intensity and duration of attacks, causing psychosomatic health disorders and negative social consequences. Although the same phenomenon is often identified as psychological terror, mobbing, bullying (Leymann, 1996). When identifying mobbing, the classical Leymann's (1993) definition is followed: attacks are recorded at least once a week and last for at least six months. This is an essential feature of an ongoing attack, distinguishing it from bullying.

There is no unambiguous answer to the question, what is the role of a victim in the beginning of the conflict, but the influence of the organizational system formed by managers is practically undoubted. However, in the future scientific research it is relevant to deal with the reasons, why in some organizations anti-harassment policy is not developed (Bryant et al., 2009), to develop cooperation between researchers and employers (Rayner et al., 2002).

The problem of the research is formulated by the questions: What organizational and individuality dimensions can become and do become the causes of mobbing in work environment? How can we shape and improve the system for the prevention of bullying after the identification of organizational and individual causes of mobbing?

Object of the research: individual and organizational causes of mobbing.

Often individual studies focus on organizational or individual causes of mobbing. The aim of the research was to provide systemic guidelines for change after the evaluation of individual and organizational causes of mobbing.

To achieve the goal, the following objectives of the research were set:

1) to determine the gaps of the organizational system which encourage mobbing;

2) to carry out the analysis of individual dimensions leading to mobbing in work environment. 
Methods of the research: the research was carried out largely on the grounds of the analysis, synthesis and generalisation of studies published in the ISI Web of Science journals.

\section{ORGANIZATIONAL CONTEXT}

The phenomenon of mobbing in Lithuania has been analysed in individual aspects in the last decade. M. Kristenson et al. (2001) compared the impact of mobbing on cardiovascular diseases in Lithuania and Sweden, V. Malinauskienè et al. (2005) related the effects of terrorization with cardiovascular diseases of teachers, P. Žukauskas and J. Vveinhardt (2009a) extended the concept of mobbing in the aspect of discrimination and found the following: socio-demographic characteristics of mobbing victims in the public and private sector organizations, the relationship of mobbing with the organizational climate, the expression of mobbing in accordance with the areas of professional field of activity, modelling managerial decisions on the prevention and intervention (Vveinhardt, 2009; Žukauskas, Vveinhardt, 2010, 2011; Vveinhardt, Žukauskas, 2012).

Organizations seek to become attractive employers and an employee wants to become a member of such organization. There are no organizations that could exist without employees' interaction. The quality of an activity result as well as profit of a business organization depend on the effectiveness and quality of this interaction and in public sector - the quality of services provided. Apart from this, there exist many aspects that embrace broad social and economical context of the relevant problem (Vveinhardt, Žukauskas, 2012). Organizational system is an important factor influencing the workplace bullying. This is proved by mobbing/bullying studies carried out in different countries, with different cultures and traditions of work organisation. However, there is still a lack of more comprehensive studies in this direction in Lithuania, so the international scientific practice is becoming more relevant.

A Swedish scientist H. Leymann (1993) was one of the first who noted the connection of work organization and mobbing. Later M. Rescha and M. Schubinskib (1996) studied these topics in detail, paying attention to the principles of management and work organization, D. Zapf (1999) and L. J. Hauge (2011 emphasised the significance of working conditions, D. Salin (2006) stressed organizational measures to prevent bullying, M. Duffy and L. Sperry (2012) analysed personnel management activities, etc.

Despite the existing cultural differences, a ternary, integrally related problem occurs in working organizations (Table 1).

Table 1. Contextual connections of organizational causes of mobbing (composed by J. Vveinhardt)

\begin{tabular}{|l|l|l|}
\hline Problem group & Sources & System context \\
\hline Organization of work & $\begin{array}{l}\text { Zapf, 1999; O'Moore, Crowley, 2011; Citoni } \\
\text { et al., 2012; Svensson, Van Genugten, 2013 }\end{array}$ & $\begin{array}{l}\text { The connection between organization of } \\
\text { work and management culture that is an } \\
\text { integral part of organizational culture }\end{array}$ \\
\hline $\begin{array}{l}\text { Organizational culture } \\
\text { and climate }\end{array}$ & $\begin{array}{l}\text { Liefooghe, Olafsson, 1999; Giorgi, 2009; } \\
\text { Vveinhardt, Žukauskas, 2012 }\end{array}$ & $\begin{array}{l}\text { There is a causal mutually related connection } \\
\text { between the context of work organization, } \\
\text { management and psychosocial context }\end{array}$ \\
\hline Management & $\begin{array}{l}\text { Agervold, Mikkelsen, 2004; Cemaloglu, } \\
\text { 2011; Mathisen et al., 2012; Appelbaum et } \\
\text { al., 2012; Vveinhardt, Žukauskas, 2012 }\end{array}$ & $\begin{array}{l}\text { Organizational culture becomes a condition } \\
\text { of management culture, however, changed by } \\
\text { the culture of the leaders }\end{array}$ \\
\hline
\end{tabular}


Systematically related organizational causes of mobbing are elaborated in the analysis of internal aspects of organization of work, management, climate and culture.

In February 2009 a survey was conducted with nurses working in a research and training hospital located in Turkey. The results showed that the aim of influencing promotion, task assignments, performance appraisal, recruitment, dismissal, allocation of equipment and operational means, together with allocation of personal benefits and organizational structure decisions, were perceived as potential political reasons for bullying by nurses. Moreover, the reasons for the various bullying behaviors were perceived as relevant to individual characteristics, namely, the perpetrators' need for power, and their psychological and private life problems (Katrinli et al., 2010). It is more difficult to victimize a victim in the organization which clearly defines the functions and competence of the employees. On the one hand, the possibility to give an employee some work beyond his competence or load him with pointless tasks, etc. in order to show the victim's "incompetence" is limited. On the other hand, according to D. Zapf (1999), in the working environment full of uncertainties there is a risk that an employee will make minor mistakes, which will be used as a pretext to attack the victim. The organizational factor that intolerable behaviour is not addressed in the regulations and it becomes difficult to identify it as mobbing also stops employees from reporting about the mobbing (Horvat, Pagon, 2012). On the other hand, many of executives are organizers of attacks, supported by colleagues or subordinates who tolerate such behaviour (Davenport et al. 1999; Martin, 2000), therefore the executives may be interested in maintaining the uncertainty in the organization. In this case not the lack of management competence is highlighted, but the management style, to which uncertainty provides a greater freedom of unethical actions and their public interpretation.

One possible reason could be that small- and medium-sized enterprises differ from larger organizations in the quality of top-down communication, which might not trigger or sustain frustration or conflicts (Baillien et al., 2011). Long-lasting studies show the trends that mobbing risk factors are related to the area of professional activities. The areas of professional activities, in which the possibility of aggression is higher, characterized by tension, frequent interpersonal contacts and long-term stress, fall into the risk zone. Higher university or higher non-university education is required from persons working in these areas. Work related with strong emotions is a potential stress factor (Johnson et al., 2005). G. Brewer and E. Whiteside (2012) found physical and psychological stress caused by attacks in prisons, S. van Eckert et al. (2011) stressed a statistically different level of job satisfaction among nursing employees who have acquired higher education and those who do not have higher education, and B. Burnes and R. Pope (2007) found that employees of the public health system suffer from mobbing more often than representatives of private organizations. D. Lewis' (1999) research, conducted in educational institutions in Wales, recorded bullying, sex-based discrimination, sexual harassment, race-based insults; the research of J. Blase et al. (2008), which involved the employees of secondary and higher education institutions of the USA, stressed the influence of demographic variables on the perception of bullying, D. Riley et al. (2011) pointed out bullying during employment in Australian educational institutions and negative effects of attacks on the employees' health. The comparison of teaching staff reactions in 
Australia and Uganda (Casimir, et al., 2012) established the fundamental difference: the reaction of respondents from Australia to bullying was more sensitive. Thus, in addition to occupational variables, demographic and cultural criteria, which influence both the nature of bullying and its acceptance, are highlighted.

High job demands were associated with a higher probability of being a target of severe bullying, which was particularly true for the very high job demands group. Low job control was also associated with a higher probability of being a target of severe bullying. Moreover, high job control buffered the negative effects of job demands on being a target of severe bullying, particularly when employees reported very little job control and high/very high job demands (Notelaers et al., 2012). Another problem of organizational system is the absence of bullying intervention and prevention measures or their inefficiency. It was found that organizational initiatives directed against bullying not only reduced the extent of bullying, but also positively affected organizational commitment (McCormack et al., 2006; Cooper-Thomas et al., 2013), with the decrease in bullying, satisfaction with managers and co-workers is increasing (McCormack et al., 2006), a negative inverse correlation between the organizational climate and mobbing and other bullying was found (Vveinhardt, Žukauskas, 2012). Victims should not be held responsible for negative psychosomatic consequences of the attack; executives are responsible for prevention of bullying (Djurkovic et al., 2006).

Explanations for and factors associated with bullying are classified into three groups, enabling structures or necessary antecedents (e.g. perceived power imbalances, low perceived costs, and dissatisfaction and frustration), motivating structures or incentives (e. g. internal competition, reward systems and expected benefits), and precipitating processes or triggering circumstances (e. g. downsizing and restructuring, organizational changes, changes in the composition of the work group) (Salin, 2003) (Figure 1).

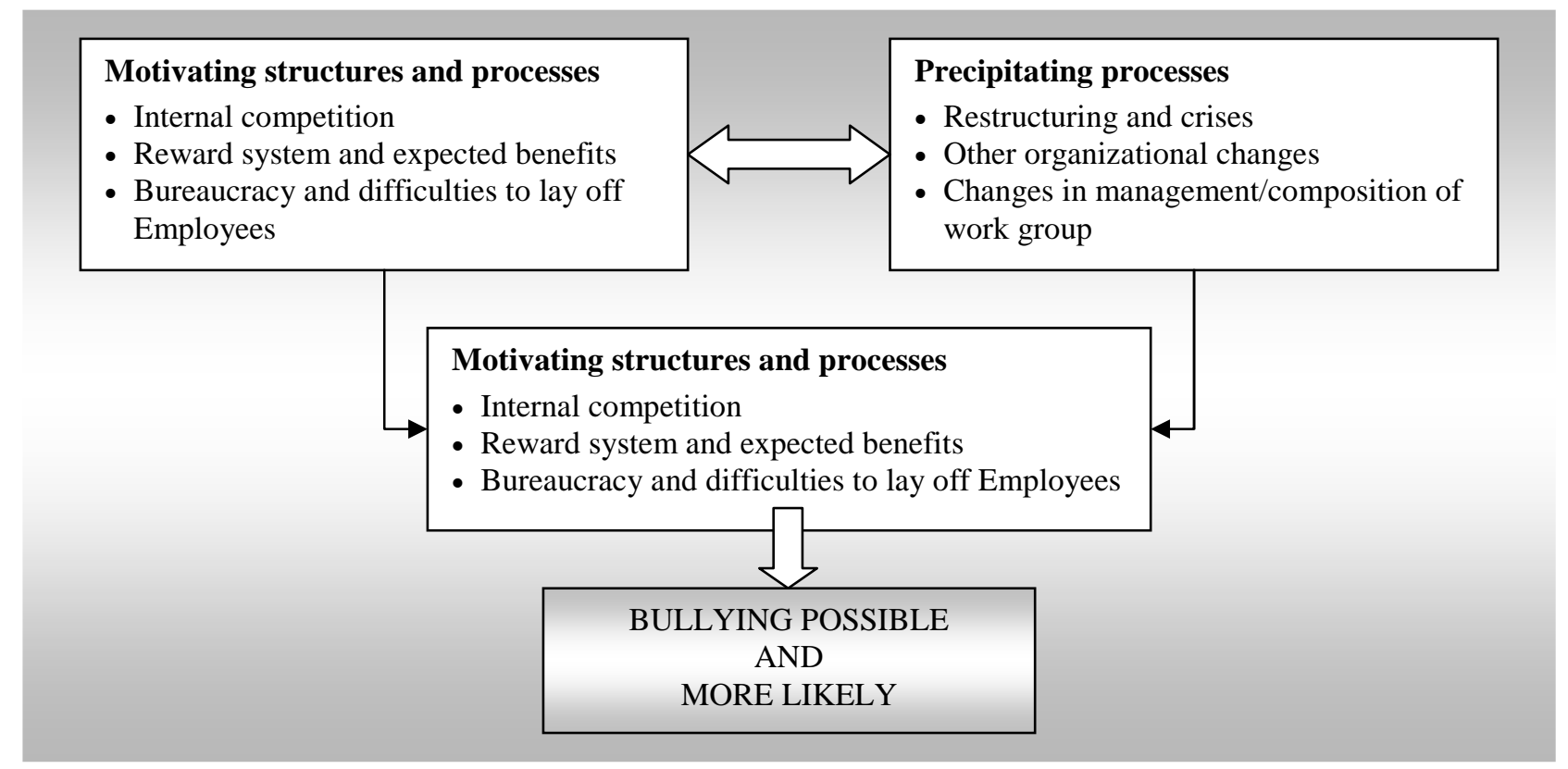

Fig. 1. Enabling, motivating and precipitating structures and processes in the work environment that contribute to bullying (Salin, 2003, p. 1218) 
To reduce job stress, anxiety and enhance control, it is proposed to improve working conditions, to introduce rotation (Aiello et al., 2008), to improve organizational climate, since poor internal climate has an influence on emergence of bullying (Giorgi, 2009; Vveinhardt, Žukauskas, 2012), to change organizational culture (Liefooghe, Olafsson, 1999; Sheehan, Griffiths, 2011), to implement reorganization in the development of ethical leadership (Appelbaum et al., 2012). The extent of bullying can be reduced by intervention measures, dialogue and training (Treven, Potocan, 2005; Djurkovic et al., 2006; Mikkelsen et al., 2011), it is recommended to eliminate the reasons, which cause fear of revenge for victims who report about attacks (Svensson, Van Genugten, 2013). In addition, it is important to develop anti-bullying projects and promote cooperation of employees and employers (Beirne, Hunter, 2013).

In summary, what can be stated about the causes of bullying/mobbing a priori, is confirmed by the results of studies, which focus attention on the management activities of the organizations, which organization's functionality depends on. Organizational psychology research formulates clear and specific tasks for managers on how to manage and adjust the management process and change organizational management system, in order to avoid bullying and mobbing.

\section{THE ROLE OF INDIVIDUAL CHARACTERISTICS AND COMPETENCES IN ATTACK}

In practice of organizational management in Lithuania an intersection of two opinions can be seen. At the level of individual causes one position is that the victim itself is to blame for the suffered attack, the other protects the victim and looks for causes in the attacker. However, it would be difficult and irresponsible to formulate an unambiguous thesis. The role of a person in mobbing attacks is not fully highlighted yet, and the results of the research carried out signify dynamics of organizational and individual causes.

In societies there are traditions determined by world cognition and human contemplation on the basis of which there is a habit to divide all people according to possession or absence of certain peculiarities like physical, psychological and others, but this conditionally natural division into groups in work organizations (and not only) can acquire a negative meaning, which encourages unequal perception of a person or a group, assault as an outside form of intolerance of differences (Vveinhardt, Žukauskas, 2012).

The empirical studies of the causes of mobbing are concentrated on the victim's personality and psychosocial factors (Einarsen, 1999). It is noted that the victims do not evaluate their role in the course of the conflict adequately (Kolodej, 2005). M. Bryant et al. (2009) have found that the inability to successfully complain about bullying leads to negative consequences for the individual himself. D. Zapf (1999) noted such individual characteristics as avoidance of conflicts, inability to recognize the conflict, low effort to integrate into the working group. However, it was stressed that not all victims of mobbing are characterized by low social competence. Although people become victims because of social incompetence as well, some cases show that attackers are characterized by higher social competence, abusing which against colleagues, a favourable assessment by the managers is retained (Treadway et al., 2013). 
It has been found that more self-sufficient employees, with greater social competence may be prone to abuse their power (Kisamore et al., 2010; Treadway et al., 2013), and the victims are more likely to have lower social competence that doesn't allow to respond to the attack adequately and resolve the conflict (Treadway et al., 2013).

S. Einarsen (1999) names competition and envy among the causes of mobbing. Hence, both personal and professional features of the choice of victims are relevant. L. Glas $\varnothing$ et al. (2007) maintain that there is no such thing as a portrait of the victim, and more than half of the victims involved in the study did not differ from the others in any way, but they note such characteristics of victims as emotional instability, honesty and extroversion, so the personality should not be ignored.

D. Lee (2002) argues that the differences in the gender dynamics could not be determined (by mobbing cases studies). M. O’Moore and N. Crowley (2011) come to the conclusion that the size of the clinical effect is not related to a person's character, but is related to painful bullying experience. There is also no reliable data, that a person's gender may be related to both the attack itself and to its consequences (Vartia, Hyyti, 2002; David, Degioanni, 2006; Ortega et al., 2009). Although it is noted that mobbing is more common in the areas of occupational activities, which are more popular among women (Vveinhardt, Žukauskas, 2012), it is relevant that women tend to talk more openly about problems at work, women accept mobbing much more often and more intensively than men do (Zapf, Warth, 1997; Vveinhardt, 2009; Žukauskas, Vveinhardt 2009b; Casimir et al.. 2012; Tomić, 2012), in addition, they are more concerned with their health (MacIntosh et al. 2011) and tend to evaluate mobbing more strictly than men (Horvat, Pagon, 2012).

The status of the potential victim in the organization and the age of the victim have a more significant impact. It was found that subordinates and seniors become victims more frequently (Gül et al., 2010). Moreover, it was found that with the increase in the length of employment in an organization, the employees' would to inform about the cases of mobbing decreases (Horvat, Pagon, 2012).

Mobbing is related to stigmatization. That is, ethnic, cultural, physical differences between individuals can become a pretext for discriminatory attacks (Vveinhardt, Žukauskas, 2012). For example, D. Lewis and R. Gunn's (2007) study in the US stated that representatives of ethnic minorities feel greater attacks than the white; M. H. Vickers (2009) emphasized bullying experienced by the disabled employees. S. J. Minton (2012) elaborates that individuals who belong to different subcultures, i. e. distinguish from other people who belong to the organization, are attacked more frequently. Moreover, cultural differences determine the means used in the process of mobbing. J. Escartín et al. (2010), who compared the cases in the Southern Europe and South America, have found that physical attacks dominate in the latter region. This extends the understanding of dynamics of mobbing causes.

On the basis of the results of the studies, the matrix of individual dimensions which influence mobbing is presented below. 


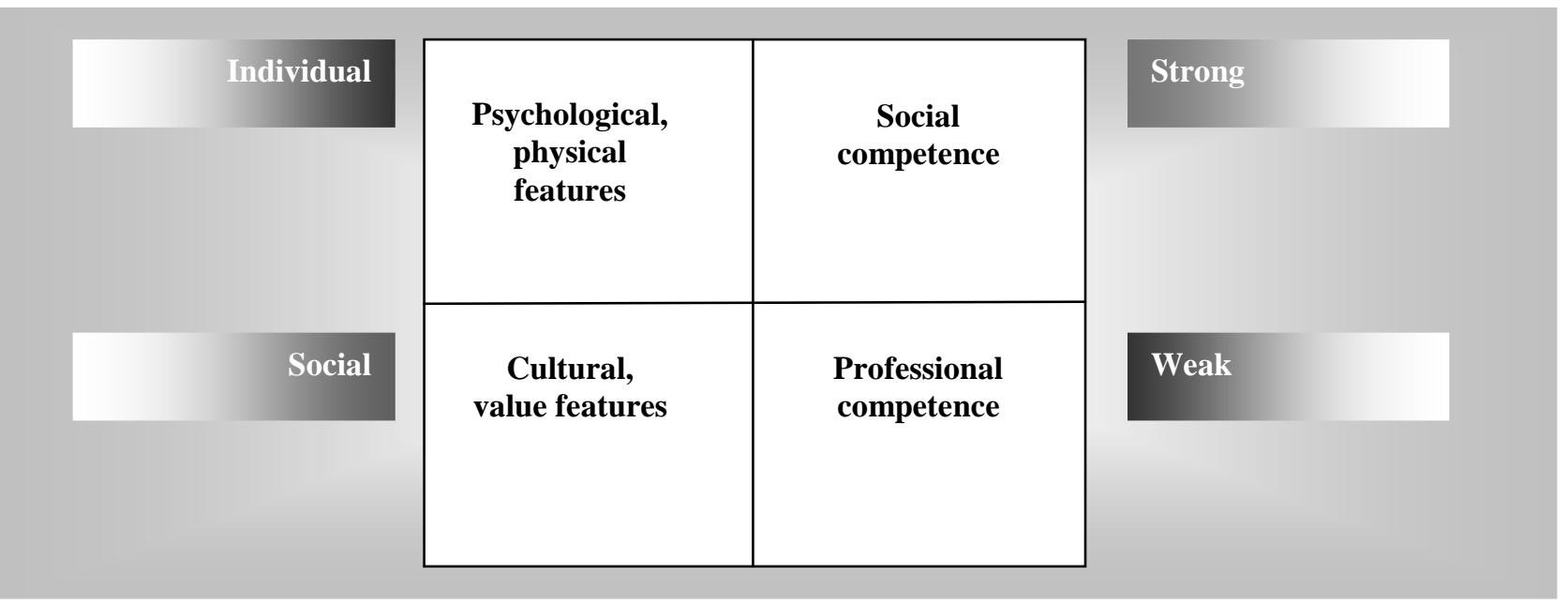

Fig. 2. The matrix of individual dimensions of mobbing (composed by J. Vveinhardt)

Empirical studies distinguish four key dimensions that affect the emergence of mobbing, regardless of the culture, in which relationships between employees are formed and implemented. Culture, values are the correlates, which alone can foster a negative reaction from co-workers, however, systematically, are not a determinant factor. Looking for the causes of mobbing in the organization, both positive and negative results reveal in the value context of interpersonal relationships. In common sense relationships in the organization become conspicuous as the complex of compatibility of interests and values. Individual characteristics, describing an employee, displayed in relations with colleagues and in professional activities, are inseparable from his / her social competence. Acquired social competencies, culture, social relationship traditions, attitudes, stereotypes can affect mobbing in a minor social context - organization and individual. This causes tension where conflicts arise when trying to break free from them. Social competence prevails in both non-systematic cases of bullying, and when they grow into mobbing. It is an important focus in the practice of management of organizations, both in predicting possible sources of conflicts, and in planning prevention policy.

Mobbing is a relevant problem not only to individuals and the organization, but also a social problem, thus it is to be solved not only on the individual but on the organizational and macro levels as well. In the organization this would include a complex of managerial decisions (diagnostic, public policy, human resource management, conflict prevention and intervention, cultural development and so on) (Vveinhardt, Žukauskas, 2012).

Therefore, to sum up, it can be argued that individual features of victims highlighted in the studies show that the attack is more likely to occur for personalities with exceptional features. However, in this case, the overall level of environmental tolerance towards the diversity of human resources is relevant as well. And the most important factor is the social competence of an employee to respond adequately to attacks and resolve them in both organizations and the individual context of relationships in work environment. Organizations, seeking to manage the conflicts of mobbing, should focus on this. 


\section{CONCLUSIONS, DISCUSSION AND FURTHER RESEARCH}

Individual and organizational reasons are related, that is, certain organizational conditions may lead to mobbing, to allow the conflict to escalate or vice versa, to act proactively. N. Johns, P. J. Menzel (1999) refuted the opinion that where the work is creative, for example, the kitchen of a high level restaurant, mobbing should not occur. The research has shown that physical exercise, fatigue, noise, heat, can provoke the assault. Organizational culture (Liefooghe, Olafsson, 1999) and climate - psychological atmosphere, which can lead to mobbing (Giorgi, 2009) may also have influence.

Thus, according to D. Zapf (1999), it is impossible to explain the causes of mobbing unambiguously, since they are complex. This was later confirmed by F. A. Moayed et al. (2006), who found the connection between organizational factors determining workplace bullying and the victim's personality.

Studies show that organizational and individual characteristics alone are not force majeure, however, managerial job mistakes and coincidence of personal features increase the risk of mobbing. Individual differences, going beyond the boundaries of the individuality context tolerated in the society and organizational reasons may become a source of bullying and mobbing. The analysis of organizational causes of mobbing has not shown anything new, what might be unknown to a professional manager, however, it reveals the gaps in managerial expertise, which damage the functionality of the organization and create conflict environment. While stating that the victim's personal profile is not the determinant cause of mobbing, and the victim is not to blame for the experienced bullying, the influence of individual characteristics in the course of bullying is not disproved. Although the influence of gender on emergence of mobbing is not proved, such characteristics as the age, the length of service, ethnic and cultural properties, the person's psychology may influence the attacks. Thus, in order to avoid mobbing, there must be investment in increasing the tolerance towards persons' differences and employees' social competencies, and managers should pay more attention to the diversity of the organization.

The matrix of individual characteristics of mobbing can be used regardless of cultural and professional medium of the organization, since it discusses both individual physical, psychological and social competences and the aspects of professional activities, as well as cultural, value aspects. With the development of social competence of the employee it can be expected that vulnerability of psychological, cultural properties will decline and the conditions for professional fulfilment will improve.

When organising a preventive system and trainings for male employees, representatives of socio-cultures, characterised by insufficient knowledge about mobbing, should be encouraged and trained to overcome traditional cultural stereotypes preventing from complaining about bullying to the organisation's management, and the management should adequately respond to bullying.

The analysis of literature has shown that many of the mobbing studies focus on psychological factors, which are carried out by psychologists and mental health professionals, however, the organizational component of the problem promotes wider involvement of managers, forming the work environment, organizational culture and climate. 
When analysing the research carried out in different cultures, the fact that the reaction to mobbing, as well as reports of intolerable co-workers' behaviour can be related to the general intolerance of the population to bullying and its regulation, should be noted. As mobbing is characterized by fraudulent behaviour, using measures of psychological impact, not all of the actions can be properly accepted as mobbing. Therefore, in prospect it would be significant to focus attention on the influence of the level of institutionalisation of mobbing both on victims' reports and on perception of intolerable behaviour. This encourages careful evaluation of statistics of the incidence of mobbing among different countries, which is influenced not only by application of measures directed against mobbing, but by subjective factors as well.

\section{REFERENCES}

1. Agervold, M., Mikkelsen, E. G. (2004). Relationships between bullying, psychosocial work environment and individual stress reactions. Work \& Stress: An International Journal of Work, Health \& Organisations, 18 (4), 336-351.

2. Aiello, A., Deitinger, P., Nardella, Ch., Bonafede, M. (2008). A tool for assessing the risk of mobbing in organizational environments: The "Val. Mob." scale. Prevention Today, 4 (3), 9-24.

3. Appelbaum, S. H., Semerjian, G., Mohan, K. (2012). Workplace bullying: Consequences, causes and controls (part two). Industrial and Commercial Training, 44 (6), 337-344.

4. Baillien, E., Neyens, I., De Witte, H. (2011). Organizational correlates of workplace bullying in smalland medium-sized enterprises. International Small Business Journal, 29 (60), 610-625.

5. Beirne, M., Hunter, P. (2013). Workplace bullying and the challenge of pre-emptive management. Personnel Review, 42 (5), 595-612.

6. Blase, J., Blase, J., Du, F. (2008). The mistreated teacher: a national study. Journal of Educational Administration, 46 (3), 263-301.

7. Brewer, G., Whiteside, E. (2012). Workplace bullying and stress within the prison service. Journal of Aggression, Conflict and Peace Research, 4 (2), 76-85.

8. Bryant, M., Buttigieg, D., Hanley, G. (2009). Poor bullying prevention and employee health: some implications. International Journal of Workplace Health Management, 2 (1), 48-62.

9. Burnes, B., Pope, R. (2007). Negative behaviours in the workplace: A study of two Primary Care Trusts in the NHS. International Journal of Public Sector Management, 20 (4), 285-303.

10. Casimir, G., McCormack, D., Djurkovic, N., Nsubuga-Kyobe, A. (2012). Psychosomatic model of workplace bullying: Australian and Ugandan schoolteachers. Employee Relations, 34 (4), 411-428.

11. Cemaloglu, N. (2011). Primary principals' leadership styles, school organizational health and workplace bullying. Journal of Educational Administration, 49 (5), 495-512.

12. Citoni, G., Mahy, B., Rycx, F. (2012). Work organization, performance and health: introduction. International Journal of Manpower, 33 (3), 224-232.

13. Cooper-Thomas, H. D., Gardner, D., O’Driscoll, M.P., Bentley, T., Catley, B., \& Trenberth, L. (2013). Neutralizing workplace bullying: The buffering effects of contextual factors. Journal of Managerial Psychology, 28 (4), 384-407.

14. Davenport, N., Schwartz, R. D., Elliott, G. P. (1999). Emotional Abuse in the American Workplace. Civil Society Publishing: Ames, Iowa.

15. Djurkovic, N., McCormack, D., Casimir, G. (2006). Neuroticism and the psychosomatic model of workplace bullying. Journal of Managerial Psychology, 21 (1), 73-88.

16. Duffy, M., Sperry, L. (2012). Mobbing: Causes, Consequences, and Solutions. Oxford Scholarship Online.

17. Eckert, S., Gaidys, U., Martin, C. R. (2011). Embitterment among German academic and non-academic nurses. Journal of Mental Health Training, Education and Practice, 6 (2), 104-112. 
18. Escartín, J. Zapf, D., Arrieta, C., Rodríguez-Carballeira, A. (2010). Workers' perception of workplace bullying: A cross-cultural study. European Journal of Work and Organizational Psychology, 20 (2), 178-205.

19. Estes, B., Wang, J. (2008). Integrative Literature Review: Workplace Incivility: Impacts on Individual and Organizational Performance. Human Resource Development Review, 7 (2), 218-240.

20. Giorgi, G. (2009). Workplace bullying risk assessment in 12 Italian organizations. International Journal of Workplace Health Management, 2 (1), 34-47.

21. Glasø, L., Matthiesen, S. B., Nielsen, M. B., Einarsen, S. (2007). Do targets of workplace bullying portray a general victim personality profile? Scandinavian Journal of Psychology, 48 (4), 313-319.

22. Gül, H., Alçalar, N., Kayı, İ., Özel, S., Özgülnar, N. (2010). Mobbing in working life and its effects on health: A cross-sectional study among privately -owned bank workers. Türkiye Klinikleri Journal of Medical Sciences, 30 (6), 1917-1927.

23. Hauge, L. J., Skogstad, A., Einarsen, S. (2011). Role stressors and exposure to workplace bullying: Causes or consequences of what and why? European Journal of Work and Organizational Psychology, 20 (5), 610-630.

24. Horvat, B. K., Paon, M. (2012). Attitudes toward Workplace Mobbing in Slovenian Research Organisations. Organizacija, 45, 159-173.

25. Yildirim, D., Yildirim, A., Timucin, A. (2007). Mobbing Behaviors Encountered By Nurse Teaching Staff. Nursing Ethics, 14 (4), 447-463.

26. Johns, N., Menzel, P. J. (1999). 'If you can't stand the heat!' ... kitchen violence and culinary art. International Journal of Hospitality Management, 18 (2), 99-109.

27. Katrinli, A., Atabay, G., Gunay, G., Cangarli, B. G. (2010). Nurses' perceptions of individual and organizational political reasons for horizontal peer bullying. Nursing Ethics, 17 (5), 614-627.

28. Kisamore, J. L., Jawahar, I. M., Liguori, E. W., Mharapara, T. L., Stone, T. H. (2010). Conflict and abusive workplace behaviors: The moderating effects of social competencies. Career Development International, 15 (6), 583-600.

29. Kolodej, Ch. (2005). Psychoterror am Arbeitsplatz und seine Bewältigung. Wien: WUV.

30. Kristenson, M., Kucinskiene, Z., Bergdahl, B., et al. (2001). Risk factors for coronary heart disease in different socioeconomic groups of Lithuania and Sweden - The LiVicordia Study. Scandinavian Journal of Public Health, 29, 140-50.

31. Lee, D. (2002). Gendered workplace bullying in the restructured UK Civil Service. Personnel Review, $31(2), 205-227$.

32. Leymann, H. (1993). Mobbing Psychoterror am Arbeitsplatz und wie man sich dagegen wehren kann. Reinbek: Rowohlt.

33. Leymann, H. (1996). The Content and Development of Mobbing at Work. European Journal of Work and Organizational Psychology, 5 (2), 165-184.

34. Liefooghe, A. P. D., Olafsson, R. (1999). "Scientists" and "amateurs": Mapping the bullying domain. International Journal of Manpower, 20 (1/2), 39-49.

35. Malinauskienè, V., Obelenis, V., Šopagienè, D. (2005). Psychological terror at work and cardiovascular diseases among teachers. Acta Medica Lituanica, 12 (2), 20-25.

36. Martin, B. (2000). Mobbing: Emotional Abuse in the American Workplace. Journal of Organizational Change Management, 13 (4), 401-446.

37. Mathisen, G. E., Øgaard, T., Einarsen, S. (2012). Individual and situational antecedents of workplace victimization. International Journal of Manpower, 33 (5), 539-555.

38. McCormack, D., Casimir, G., Djurkovic, N., Yang, L. (2006). The concurrent effects of workplace bullying, satisfaction with supervisor, and satisfaction with co-workers on affective commitment among schoolteachers in China. International Journal of Conflict Management, 17 (4), 316-331.

39. Minton, S. J. (2012). Alterophobic bullying and pro-conformist aggression in a survey of upper secondary school students in Ireland. Journal of Aggression, Conflict and Peace Research, 4 (2), 86-95. 
40. Notelaers, G., Baillien, E., De Witte, H., Einarsen, S., Vermunt, J. K. (2012). Testing the strain hypothesis of the Demand Control Model to explain severe bullying at work. Economic and Industrial Democracy, 34 (1), 69-87.

41. O'Moore, M., Crowley, N. (2011). The clinical effects of workplace bullying: a critical look at personality using SEM. International Journal of Workplace Health Management, 4 (1), 67-83.

42. Ortega, A., Høgh, A., Pejtersen, J. H., Olsen, O. (2009). Prevalence of workplace bullying and risk groups: a representative population study. International Archives of Occupational and Environmental Health, 82 (3), 417-426.

43. Rayner, C., Hoel, H., Cooper, C. L. (2002). Workplace Bullying: What We Know, Who Is To Blame and What Can We Do? London: Taylors and Francis.

44. Rescha, M., Schubinskib, M. (1996). Mobbing-prevention and management in organizations. European Journal of Work and Organizational Psychology, 5 (2), 295-307.

45. Riley, D., Duncan, D. J., Edwards, J. (2011). Staff bullying in Australian schools. Journal of Educational Administration, 49 (1), 7-30.

46. Salin, D. (2003). Ways of Explaining Workplace Bullying: A Review of Enabling, Motivating and Precipitating Structures and Processes in the Work Environment. Human Relations, 56 (10), 1213-1232.

47. Salin, D. (2006). Organizational Measures Taken against Workplace Bullying: The Case of Finnish municipalities. Helsinki: Swedish School of Economics and Business Administration.

48. Svensson, J., van Genugten, M. (2013). Retaliation against reporters of unequal treatment: Failing employee protection in The Netherlands. Equality, Diversity and Inclusion: An International Journal, $32(2), 129-143$.

49. Tomić, M. A. (2012). Mobbing: the incidence of mobbing activities and differences regarding workplace and gender. Megatrend Review, 9 (1), 243-252.

50. Treadway, D. C., Shaughnessy, B. A., Breland, J. W., Yang, J., Reeves M. (2013). Political skill and the job performance of bullies. Journal of Managerial Psychology, 28 (3), 273-289.

51. Van Heugten, K. (2013). Resilience as an underexplored outcome of workplace bullying. Qualitative Health Research, 23 (3), 291-301.

52. Vartia, M., Hyyti, J. (2002). Gender differences in workplace bullying among prison officers. European Journal of Work and Organizational Psychology, 11 (1), 113-126.

53. Vveinhardt, J. (2009). Mobingo kaip diskriminacijos darbuotoju santykiuose diagnozavimas siekiant gerinti Lietuvos organizaciju klimata: daktaro disertacija. Kaunas: VDU leidykla.

54. Vveinhardt, J. (2010). Mobingo kaip diskriminacijos darbuotojų santykiuose diskursas. Jaunuju mokslininku darbai, 1 (26), 142-148.

55. Vveinhardt, J., Žukauskas, P. (2012). Mobingas darbuotoju santykiuose: individas, organizacija, sociumas: monografija. Kaunas: VDU leidykla.

56. Zapf, D. (1999). Organisational, work group related and personal causes of mobbing / bullying at work. International Journal of Manpower, 20 (1 / 2), 70-85.

57. Zapf, D., Warth, K. (1997). Mobbing: Subtile Kriegsfuhrung am Arbeitsplatz. Psychologie Heute, 24 (8), 20-25.

58. Žukauskas, P., Vveinhardt, J. (2009a). Socio-demographic characteristics of mobbing and discrimination in employee relations. Transformations in Business \& Economics, 8 (3 / 18), 128-147.

59. Žukauskas, P., Vveinhardt, J. (2009b). Diagnosis of Mobbing as Discrimination in Employee Relations. Engineering Economics, 4 (64), 103-113.

60. Žukauskas, P., Vveinhardt, J. (2010). The model of managerial intervention decisions of mobbing as discrimination in employees' relations in seeking to improve organization climate. Engineering Economics, 21 (3), 306-314.

61. Žukauskas, P., Vveinhardt, J. (2011). Mobbing Diagnosis Instrument: Stages of Construction, Structure and Connectedness of Criteria. Journal of Business Economics and Management, 12 (2), 400-416. 


\title{
SISTEMINIAI INDIVIDUALIŲ IR ORGANIZACINIŲ DIMENSIJŲ VEKTORIAI PASIREIŠKIANT MOBINGUI DARBUOTOJŲ SANTYKIUOSE
}

\section{Jolita Vveinhardt}

\author{
Lietuvos sporto universitetas, Kaunas, Lietuva
}

\section{SANTRAUKA}

Straipsnyje analizuojami ir sisteminami naujausių tyrimų rezultatai, nubrèžiami organizacijos aplinkos vektoriai, kurių krypties pokytis turètų prevencini poveiki reiškiniui. Mobingo priežastys nagrinejjamos dviem aspektais - individualiu ir organizaciniu, siekiant atsakyti i klausimą, kaip ívertinus šiuos kriterijus galima sumažinti mobingo riziką vadybiniais veiksmais. Organizacinès sistemos vaidmuo išryškinamas kaip veiksnys, lemiantis patyčių atsiradimą darbo aplinkoje. Individualių mobingo priežasčių analizè atskleidžia, kad puolimai, susiję su patyčiomis, labiau tikètini prieš asmenis, turinčius išskirtinių savybių. Nustatyta organizaciniu ir individualių veiksnių dinamika, turinti itakos patyčioms ir mobingui organizacijoje eskaluoti. Susistemintos ankstesnių ir naujausių tyrimų išvados leidžia formuluoti temas naujiems mobingo tarp organizacijos darbuotojų tyrimams atlikti.

Tyrimo problema formuluojama klausimu: kokios organizacinès ir individualios dimensijos gali tapti ir tampa mobingo darbo aplinkoje priežastimis ir kaip, identifikavus organizacines ir individualias mobingo priežastis, formuoti bei tobulinti patyčių prevencijos sistemą?

Tyrimo objektas: individualios ir organizacinès mobingo priežastys.

Atliekant tyrimus dažnai gilinamasi i organizacines arba individualias mobingo priežastis. Šio tyrimo tikslas - įvertinti individualias ir organizacines mobingo priežastis ir numatyti sistemines pokyčių gaires.

\section{Tyrimo uždaviniai:}

1) nustatyti organizacinès sistemos trūkumus, skatinančius mobingą;

2) atlikti individualių dimensijų, skatinančių mobingą darbo aplinkoje, analizę.

Tyrimo metodai. Tyrimas atliktas daugiausia remiantis ISI Web of Science žurnaluose paskelbtu studijų analize, sinteze ir apibendrinimu.

Tyrimo rezultatai. Tyrimai rodo, kad ir netinkamus organizacinius, ir individualius veiksnius atskirai galima įveikti, tačiau, jei vadybinio darbo klaidos ir asmeninès savybès sutampa, mobingo rizika padidejja. Organizuojant prevencinę sistemą ir mokymus darbuotojai vyrai, priklausantys sociokultūrinėms grupèms, kurioms būdingas žinių apie mobingą trūkumas, turètų būti skatinami ir mokomi įveikti tradicinius kultūrinius stereotipus, trukdančius pranešti apie patyčias organizacijos vadovybei, o pastarajai - adekvačiai reaguoti i patyčias. Nustatyta, kad daugeli mobingo tyrimų atlieka psichologai ir psichikos sveikatos specialistai, kurie koncentruojasi i psichologinius veiksnius, tačiau organizacinis problemos komponentas skatina plačiau įsitraukti vadybininkus, kuriančius darbinę aplinką, organizacijos kultūrą ir klimatą. Dėmesys atkreiptinas ị tai, kad reakcija į mobingą ir pranešimai apie neleistiną darbuotojų elgesi gali būti susiję su bendru žmonių nepakantumu patyčioms ir jų reglamentavimu. Kadangi mobingui būdingas apgaulingas elgesys naudojant psichologinio poveikio priemones, ne visi veiksmai gali būti tinkamai akceptuojami kaip mobingas.

Raktažodžiai: mobingas, patyčios, organizacinè sistema, individas, prevencija. 


\section{СИСТЕМНЫЕ ВЕКТОРЫ ИНДИВИДУАЛЬНЫХ И ОРГАНИЗАЦИОННЫХ ДИМЕНСИЙ ПРИ ВОЗНИКНОВЕНИИ МОББИНГА В ОТНОШЕНИЯХ МЕЖДУ РАБОТНИКАМИ}

\section{Йолита Ввейнхардт}

Литовский университет спорта, Каунас, Литва

\section{РЕЗЮМЕ}

Цель исследования данной статьи достигается при помощи анализа и систематизации результатов новейших исследований, намечаются векторы организационной среды, изменение направления которых имело бы превентивное воздействие на явление. Причины моббинга анализируются в индивидуальном и организационном аспектах с целью ответить на вопрос, как оценивая эти критерии можно уменьшить риск моббинга управленческими действиями. Роль организационной системы выделяется как фактор, предопределяющий появление издевательств между работниками. Анализ отдельных причин моббинга показывает, что нападения, связанные с издевательствами, более вероятны на индивиды, которым свойствены исключительные свойства. Установлена динамика организационных и индивидуальных факторов, которая оказывает влияние на проявление издевательства в организации и эскалацию моббинга. Систематизированные выводы более ранних и новейших исследований ведут к формулированию тем для новых исследований моббинга в отношенях между работниками организаций.

Проблема исследования формулируется как вопрос: какие организационные и индивидуальные дименсии могут стать и становятся причинами моббинга в отношениях между работниками и как после выявления организационных и индивидуальных причин моббинга формировать и совершенствовать систему для предотвращения издевательств?

Объект исследования: индивидуальные и организационные причины моббинга.

Часто отдельные исследования углубляются в организационные или индивидуальные причины моббинга. Цель данного исследования - оценить индивидуальные и организационные причины моббинга и наметить системные принципы для изменений.

\section{Задачи исследования:}

1) определить недостатки организационной системы, стимулирующие возникновение моббинга;

2) проанализировать отдельные дименсии, поощряющие моббинг среди работников.

Методы исследования: исследование проводилось по большей части на основании анализа, синтеза и обобщения исследований, опубликованных в журналах ISI Web of Science.

Результаты исследования. Исследования показывают, что одни организационные и индивидуальные характеристики по отдельности не являются форс-мажором, однако ошибки управленческой работы и совпадение личных особенностей увеличивают риск моббинга. Организовывая превентивную систему и обучая работников мужского пола, представителей социокультур, для которых характерны недостаточные знания о моббинге, следует поощрять и обучать преодолевать традиционные культурные стереотипы, мешающие сообщать об издевательствах руководству организации, а руководству - адекватно реагировать на издевательства. Установлено, что многие исследования моббинга, которые осуществляются психологами и психиатрами, сосредотачиваются на психологических факторах, однако организационный компонент 
проблемы способствует более активному участию руководителей, формирующих рабочую среду, культуру и климат организации. Необходимо обратить внимание на тот факт, что реакция на моббинг, а также сообщения о недопустимом поведении сотрудников могут быть связаны с общей нетерпимостью популяции к издевательствам и их регламентированием. Поскольку моббинг характеризуется обманчивым поведением с использованием психологических мер воздействия, не все действия могут быть должным образом акцептированы как моббинг.

Ключевые слова: моббинг, издевательства, организационная система, индивид, превенция. 